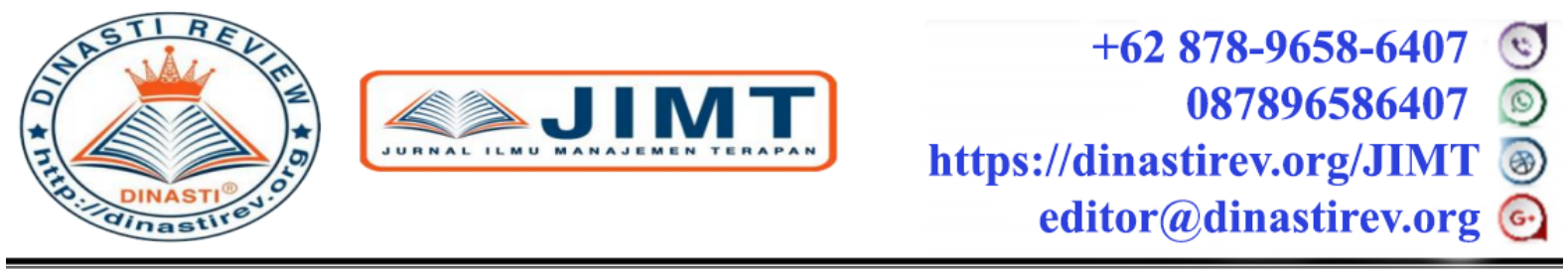

\title{
IMPLEMENTASI ANALISIS SWOT DALAM PERENCANAAN STRATEGI BERSAING PERUSAHAAN MANUFAKTUR KIMIA (Studi Kasus Pada PT. ABC)
}

Agus Mangiring Siburian')

1) Universitas Mercu Buana, Jakarta, Indonesia

\begin{tabular}{|c|c|}
\hline $\begin{array}{r}\text { Correspo } \\
\text { Agus Mar }\end{array}$ & $\begin{array}{l}\text { Abstrak: Indonesia merupakan salah satu negara } \\
\text { berkembang dengan tingkat pertumbuhan industri yang } \\
\text { tinggi. Persaingan bisnis dalam industri manufaktur saat } \\
\text { ini semakin ketat, karena itu perusahaan harus } \\
\text { membutuhkan strategi agar dapat tetap bertahan atau } \\
\text { bahkan dapat unggul dalam persaingan. Tidak terlebih } \\
\text { bagi PT. ABC sebagai salah satu perusahaan } \\
\text { manufakturkimia yang produknya digunakan diberbagai } \\
\text { industri membutuhkan strategi yang tepat di tengah } \\
\text { ketatnya persaingan bisnis. Latar belakang masalah dari } \\
\text { penelitian ini yaitu untuk mengidentifikasi faktor-faktor } \\
\text { internal dan ekseternal perusahaan yang mempengaruhi } \\
\text { strategi serta strategi yang tepat bagi perusahaan untuk } \\
\text { bersaing. Tujuan dari penelitian ini yaitu untuk } \\
\text { memberikan usulan atau rekomendasi strategi bisnis } \\
\text { yang digunakan oleh perusahaan. Metode penelitian } \\
\text { yang digunakan dalam penelitian ini adalah metode } \\
\text { deskriptif pada studi kasus yang diambil dari PT. ABC. } \\
\text { Metode analisis data pada penelitian yang digunakan } \\
\text { yaitu dengan menggunakan analisis SWOT dengan } \\
\text { menggunakan matriks IFAS dan EFAS yang kemudian } \\
\text { disusun untuk mengertahui strategi yang dapat } \\
\text { direkomendasikan kepada perusahaan. } \\
\text { Kata Kunci: Strategi Bersaing, SWOT, IFAS, EFAS } \\
\text { dan Manufaktur. }\end{array}$ \\
\hline
\end{tabular}

\section{PENDAHULUAN}

Indonesia merupakan salah satu negara berkembang dengan tingkat pertumbuhan industri yang tinggi. Didukung dengan berkembangnya teknologi mengakibatkan semakin pesatnya perkembangan industri manufaktur di dunia termasuk juga di Indonesia. Perkembangan industri manufaktur tersebut diiringi dengan meningkatnya kebutuhan masyarakat terhadap produk-produk hasil industri manufaktur. Produk dari industri manufaktur kimia saat ini telah menjadi kebutuhan hampir di semua bidang kehidupan seharihari. Oleh karena itu berbagai industri manufaktur kimia di indonesia sangat beragam. Persaingan bisnis dalam industri manufaktur saat ini semakin ketat, oleh karena itu perusahaan harus membutuhkan strategi agar dapat tetap bertahan atau bahkan dapat unggul 
dalam persaingan. Menurut data yang diperoleh dari Badan Pusat Statistik (2020) pertumbuhan industri manufaktur besar dan sedang tahun 2019 naik sebesar 4,01 persen terhadap tahun 2018. Kemudian pada triwulan IV tahun 2019 naik sebesar 0,09 persen ( $q$-to$q$ ) terhadap triwulan III tahun 2019. Industri yang mengalami kenaikan produksi tertinggi adalah industri bahan kimia dan barang dari bahan kimia, yang naik 13,07 persen. Oleh karena itu perusahaan manufaktur harus memiliki strategi bersaing yang tepat untuk terus dapat tumbuh dan bersaing di pasar. Strategi yang dibangun oleh manajemen perusahaan akan memiliki dampak yang signifikan terhadap kesuksesan atau kegagalan suatu perusahaan serta pada kebangkrutan atau bertahan hidup perusahaan tersebut di pasar.

PT. ABC merupakah salah satu perusahaan manufaktur kimia yang memproduksi asam sulfat beserta produk turunannya sejak tahun 1979. Asam sulfat $\left(\mathrm{H}_{2} \mathrm{SO}_{4}\right)$ merupakan salah satu bahan kimia utama dan pembantu yang digunakan dalam berbagai proses industri kimia dan farmasi dan permintaannya setiap tahun cenderung naik dikarenakan pertumbuhan industri bahan kimia dan barang dari bahan kimia yang terus naik dan beragam. Asam sulfat merupakan salah satu bahan baku dan penunjang yang sangat penting dan banyak dibutuhkan dalam industri kimia. Kegunaan utama (60\% dari total produksi di seluruh dunia) asam sulfat adalah dalam produksi asam fosfat, yang digunakan untuk membuat pupuk, penyulingan minyak bumi, manufaktur bahan peledak, farmasi, deterjen, plastik, kertas dan pulp. Mengingat pentingnya asam sulfat, maka kebutuhan negara terhadap asam sulfat dapat dijadikan salah satu tolak ukur kemajuan industri negara tersebut (Hakim dkk, 2018). Selain memproduksi asam sulfat sebagai produk utama, PT. ABC juga memproduksi produk turunan dari asam sulfat seperti asam sulfamat yang digunakan sebagai bahan baku pemanis buatan, bahan baku produk pembersih metal, dan bahan baku farmasi. Kemudian ada produk aluminium sulfat yang sebagian besar digunakan sebagai bahan penjernih air baku dan air imbah yang digunakan di hampir semua industri, kemudian ada produk amonium sulfat yang merupakan salah satu jenis pupuk serta kalium sulfat yang merupakan salah satu jenis pupuk dengan produk sampingnya yaitu asam klorida yang banyak digunakan dalam berbagai industri, terutama sebagian digunakan dalam industri metal. PT. ABC memiliki 2 pabrik yang berlokasi di Tangerang dan Karawang serta berkantor pusat di Jakarta. Pemilihan lokasi pabrik di sesuaikan dengan keberadaan industri yang menggunakan produk asam sulfat sehingga memudahkan untuk pendistribusiannya, kemudian kantor pusat yang berlokasi di Jakarta bertujuan untuk mempermudah aktifitas penjualan dimana sebagian besar perusahaan bahan kimia dan barfang dari kimia berkantir pusata di Jakarta. Pemilihan lokasi pabrik dan kantor merupakan salah satu strategi perusahaan untuk dapat lebih dekat dengan pasar dan mempermudah akses distribusi barang, serta pengembangan produk asam sulfat menjadi beberapa produk turunan merupakan strategi dari perusahaan untuk terus bertumbuh dalam ketatnya persaingan pada industri manufaktur bahan kimia dan barang dari kimia. Suatu perusahaan harus dapat melakukan berbagai operasi dan strategi untuk menguasai posisi pasar, dan berusaha untuk meningkatkan juga mengembangkan kualitas atau kualitas produk (Brata dkk, 2017).

Setiap perusahaan untuk dapat menghadapi lingkungan bisnis yang kompetitif dan dapat bersaing memerlukan suatu perencanaan strategi yang baik, tidak hanya berorientasi pada masa yang akan datang namun juga harus dapat mengantisipasi perubahan dalam jangka pendek dan menengah. Perencanaan strategi tersebut dimulai dari membuat analisis 
mengenai konteks bisnis yang dijalankan perusahaan, analisis lingkungan internal dan analisis lingkungan eksternal perusahaan sehingga akan dapat diketahui bagaimana posisi perusahaan sebenarnya. Oleh karena itu untuk mempelajari implementasi strategi bersaing yang digunakan oleh PT. ABC akan dibahas lebih lanjut pada penelitian ini dengan menganalisis strategi manajemen yang digunakan. Dari latar belakang yang telah dijelaskan diatas adapun identifikasi masalah dari penelitian ini yaitu: 1) Mengidentifikasi kekuatan dan kelemahan (faktor internal) yang dimiliki oleh perusahaan, 2) Mengindentifikasi peluang dan ancaman (faktor eksternal) yang dimilki perusahaan, serta 3) Alternatif strategi apa yang dapat diterapkan perusahaan agar mencapai strategi bersaing.

Adapun tujuan dari penelitian ini yaitu : 1) Mengetahui kekuatan dan kelemahan yang dimiliki oleh perusahaan, 2) Mengetahui peluang dan ancaman dari eksternal perusahaan, 3) Merumuskan strategi bisnis perusahaan dengan menggunakan analisis SWOT, dan 4) Memberikan usulan atau rekomendasi strategi bisnis yang digunakan oleh perusahaan.

Dari latar belakang, identifikasi masalah, dan tujuan penelitian di atas manfaat yang diharapkan dengan adanya penelitian ini yaitu rekomendasi dari hasil penelitian ini dapat membantu perusahaan dalam menyusun suatu perencanaan yang baik di masa yang akan datang dan merupakan salah satu analisis yang efektif bagi perkembangan perusahaan serta dapat dijadikan sebagai rekomendasi dalam penyusunan strategi perusahaan dalam bersaing di masa yang akan datang. Selain itu penelitian ini diharapkan dapat menambah informasi dan menjadi referensi bagi penulis lain dalam melakukan penelitian dengan masalah yang sama serta dapat mengembangkan penelitian selanjutnya.

\section{KAJIAN PUSTAKA}

Menurut David (2009), manajemen strategi adalah ilmu mengenai perumusan, pelaksanaan dan evaluasi keputusan-keputusan lintas fungsi yang memungkinkan organisasi mencapai tujuannya. Manajemen strategi adalah suatu proses pengambilan keputusan dan tindakan yang mengarah kepada pengembangan strategi yang efektif atau yang membantu perusahaan mencapai tujuannya. Tahapan dalam manajemen strategi menurut David (2009) yaitu :

a. Perumusan strategi : Meliputi kegiatan untuk mengembangkan visi dan misi organisasi, mengidentifikasi peluang dan ancaman eksternal organisasi, menentukan kekuatan dan kelemahan internal organisasi, menetapkan tujuan jangka panjang organisasi, membuat sejumlah strategi alternatif untuk organisasi, serta memilih strategi tertentu untuk digunakan.

b. Pelaksanaan strategi : Mengharuskan perusahaan untuk menetapkan sasaran tahunan, membuat kebijakan, memotivasi karyawan, dan mengalokasikan sumber daya sehingga perumusan strategis dapat dilaksanakan. Pelaksanaan strategis mencakup pengembangan budaya yang mendukung strategi, penciptaan struktur organisasi yang efektif, pengarahan kembali usaha-usaha pemasaran, penyiapan anggaran, pengembangan dan pemanfaatan sistem informasi, serta menghubungkan kompensasi untuk karyawan dengan kinerja organisasi.

c. Evaluasi strategi : Tahap ini merupakan tahap akhir dari manajamen strategi tiga kegiatan pokok dalam evaluasi strategi adalah : Mengkaji ulang faktorfaktor eksternal dan internal 
yang menjadi landasan perumusan strategi yang diterapkan sekarang ini. Kemudian mengukur kinerja, melakukan tindakantindakan korektif. Evaluasi strategi perlu dilakukan karena keberhasilan saat ini bukan merupakan jaminan untuk keberhasilan di hari esok.

Analisis SWOT menurut Ege dan Yasar (2017) merupakan analisis yang digunakan untuk perencanaan strategis dan manajemen strategis dalam perusahaan. Dapat digunakan secara efektif untuk membangun strategi perusahaan dan strategi kompetitif. Berdasarkan dengan pendekatan sistem, perusahaan merupakan keutuhan yang berinteraksi dengan lingkungan dan terdiri dari berbagai sub-sistem. Dalam pengertian ini, sebuah perusahaan berada di dua lingkungan, satu berada di dalam diri lingkungan perusahaan sendiri serta berada di luar perusahaan. Menurut Rangkuti (2014) analisis SWOT adalah metode perencanaan strategis yang digunakan untuk mengevaluasi kekuatan (strengths), kelemahan (weaknesses), peluang (opportunities), dan ancaman (threats) dalam suatu proyek atau suatu spekulasi bisnis. Keempat faktor analisis tersebut membentuk akronim SWOT (strengths, weaknesses, opportunities, dan threats). Analisis kekuatan (strengths) dan kelemahan (weaknesses) merupakan bagian dari analisis internal perusahaan, sedangkan peluang (opportunities) dan ancaman (threats) merupakan bagian dari analisis eksternal perusahaan. Analisis SWOT adalah proses yang melibatkan empat area analisis menjadi dua dimensi. Analisis SWOT memiliki empat komponen yaitu kekuatan, kelemahan, peluang, dan ancaman. Kekuatan dan kelemahan adalah faktor internal dan bagian dari perusahaan, sedangkan peluang dan ancaman adalah faktor eksternal dan bagian dari lingkungan. Analisis SWOT biasanya dibuat dalam kotak empat kuadran yang memungkinkan ringkasan yang disusun sesuai dengan empat judul bagian. Tabel berikut adalah Analisis SWOT, dengan empat elemennya dalam matriks $2 \times 2$.

\section{Tabel 1. Komponen Analisis SWOT}

Kekuatan Perusahaan

Kelemahan Perusahaan

Peluang Lingkungan

Ancaman Lingkungan
Karakteristik yang memberikan keunggulan dibandingkan industri yang lain

Karakteristik yang menempatkan pada posisi yang relatif tidak menguntungkan terhadap yang lain

Elemen eksternal pada lingkungan yang memberi manfaat bagi perusahaan

Elemen eksternal pada lingkungan yang dapat menyebabkan masalah bagi perusahaan

Perpaduan antara analisis internal dan eksternal perusahaan digunakan untuk merumuskan dan mengambil keputusan dalam strategi manajemen yang disebut sebagai analisis SWOT. Proses analisis ini melibatkan penentuan tujuan yang spesifik dari spekulasi bisnis dan mengidentifikasi faktor internal dan eksternal yang mendukung dan yang tidak dalam mencapai tujuan tersebut. Dengan menggunakan analisis SWOT maka menejemen dapat mengetahui apa yang menjadi kekuatan dan kelemahan perusahaan serta peluang bagi perusahaan dan ancaman yang mungkin akan muncul dimana semua hal tersebut dapat membentuk strategi yang dapat digunakan untuk keberlanjutan bisnis, pengembangan arah bisnis dan bahkan keunggulan bersaing terhadap kompetitornya. Pemahaman yang baik mengenai strategi dan konsep-konsep lain yang berkaitan sangatlah penting untuk menentukan suksesnya strategi yang akan disusun, konsep-konsep tersebut antara lain 
meliputi distinctive competence: yaitu suatu perusahaan yang memiliki kekuatan yang tidak mudah ditiru oleh perusahaan pesaing, meliputi keahlian tenaga kerja dan kemampuan sumberdaya. Serta competitive advantage: yaitu kegiatan spesifik yang dikembangkan oleh perusahaan agar lebih unggul dibandingkan dengan pesaingnya.

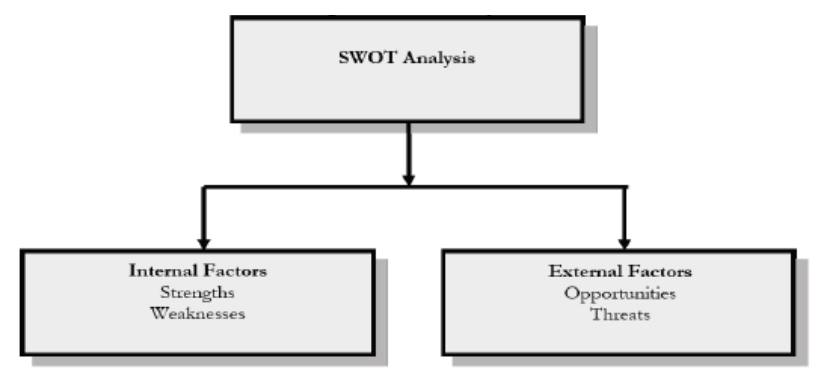

Sumber : Ege dan Yasar (2017)

Gambar 1. Analisis SWOT

Kekuatan dan peluang sangat membantu untuk mencapai tujuan perusahaan. Dan hal ini akan menguntungkan untuk perusahaan. Kelemahan dan ancaman berbahaya untuk mencapai tujuan perusahaan dan hal ini tidak menguntungkan bagi organisasi. Oleh karena itu, yang mendasari setiap pemilihan strategi yang berhasil adalah analisis kekuatan dan kelemahan internal organisasi yang ditimbulkan oleh lingkungan internal dan peluang serta ancaman yang ditimbulkan oleh lingkungan eksternal. Dengan kata lain, peran analis adalah mencoba menyesuaikan analisis eksternal dan internal untuk menyeimbangkan kekuatan dan kelemahan perusahaan terhadap peluang dan ancaman dari lingkungan.

Tabel 2. Kerangka Analisis SWOT

\begin{tabular}{|c|c|c|c|}
\hline \multicolumn{4}{|c|}{ Kemungkinan Kekuatan dan Kelemahan Organisasi } \\
\hline Pemasaran & Distribusi & Kepemimpinan & $\begin{array}{l}\text { Kualitas } \\
\text { produk/jasa }\end{array}$ \\
\hline Nama brand & Skala ekonomi & Lokasi & Promosi \\
\hline Channel management & Pemindaian lingkungan & Manajemen & Public relations \\
\hline Reputasi perusahaan & Sumber finansial & Manufaktur dan operasi & Purchasing \\
\hline Sistem informasi komputer & Forecasting & Marektshare & Quality control \\
\hline Sistem kontrol & Lobi pemerintah & Struktur organisasi & $\begin{array}{l}\text { Research \& } \\
\text { Development }\end{array}$ \\
\hline Biaya & Sumber daya manusia & Fasilitas fisik/peralatan & Penjualan \\
\hline Customer loyalty & Manajemen gudang & Diferensiasi produk/jasa & Teknologi \\
\hline Pengambilan keputusan & \multicolumn{3}{|l|}{ Hubungan dengan karyawan } \\
\hline \multicolumn{4}{|c|}{ Sumber Kemungkinan Peluang dan Ancaman Lingkungan } \\
\hline Tekanan ekonomi & $\begin{array}{l}\text { Tekanan politik } \quad \text { dan } \\
\text { hukum }\end{array}$ & Tekanan sosial & Tekanan teknologi \\
\hline Tekanan industri & & & \\
\hline
\end{tabular}

(Ege dan Yasar, 2017)

Kekuatan (Strenghts) adalah karakteristik yang menambah nilai pada sesuatu dan membuatnya lebih istimewa daripada yang lain. Kekuatan berarti bahwa ada sesuatu yang 
lebih menguntungkan jika dibandingkan dengan sesuatu yang lain. Dalam pengertian ini, kekuatan mengacu pada karakteristik positif, menguntungkan, dan kreatif. Kekuatan pada perusahaan melibatkan sifat dan kemampuan dimana suatu perusahaan memperoleh keunggulan dibandingkan perusahaan lain dan perusahaan pesaing yang terungkap sebagai hasil dari analisis lingkungan internalnya. Dengan kata lain, kekuatan perusahaan mendefinisikan karakteristik dan situasi di mana suatu perusahaan lebih efektif dan efisien dibandingkan dengan pesaing mereka. Suatu perusahaan dapat digambarkan sebagai kuat, setara atau lemah dibandingkan dengan pesaing mereka berdasarkan lima kriteria, yaitu: situasi pasar relatif, struktur keuangan relatif, kapasitas relatif produksi dan teknis, penelitian relatif dan potensi pengembangan, kapasitas manusia relatif dan efektivitas manajemen. Kekuatan perusahaan terdiri dari kompetensi perusahaan yang berperan aktif dalam mencapai tujuan perusahaan. Sebelum bertindak ketika menghadapi masalah atau peluang, perusahaan harus mengetahui potensi yang dimilikinya dan aspek-aspek yang membuatnya lebih menguntungkan daripada para pesaingnya. Menjadi kuat dan memiliki kekuatan sangat penting bagi suatu organisasi. Kalau tidak, peluang yang diciptakan oleh lingkungan luar tidak dapat digunakan. Selain itu, organisasi harus menjawab ancaman lingkungan luar dengan menggunakan kekuatannya. Semua masalah ini menyoroti pentingnya kekuatan perusahaan.

Kelemahan (Weaknesses) mengacu pada tidak memiliki bentuk dan kompetensi yang diperlukan untuk sesuatu. Kelemahan berarti bahwa ada sesuatu yang lebih tidak menguntungkan jika dibandingkan dengan sesuatu yang lain. Dalam hal ini, kelemahan adalah karakteristik yang negatif dan tidak menguntungkan. Kelemahan pada perusahaan mengacu pada situasi dimana keberadaan saat ini dan kapasitas kemampuan suatu perusahaan lebih lemah dibandingkan dengan perusahaan lain dan pesaing. Dengan kata lain, kelemahan perusahaan berarti aspek atau kegiatan dimana suatu perusahaan kurang efektif dan efisien dibandingkan dengan pesaingnya. Aspek-aspek ini secara negatif mempengaruhi kinerja perusahaan dan melemahkan perusahaan di antara para pesaingnya. Akibatnya, perusahaan tidak dapat menanggapi kemungkinan masalah atau peluang, dan tidak dapat beradaptasi dengan perubahan. Bagi perusahaan, penting untuk mengetahui kelemahannya sebagai kekuatannya. Alasannya adalah bahwa tidak ada strategi yang dapat dibangun di atas kelemahan. Kelemahan organisasi yang berpotensi memimpin organisasi menuju inefisiensi dan ketidakefektifan harus diketahui dan diperbaiki. Memecahkan masalah yang ada yang akan menyebabkan kesulitan dan keterbatasan untuk rencana dan strategi jangka panjang, dan meramalkan masalah potensial adalah wajib.

Peluang (Opportunities) adalah situasi atau kondisi yang cocok untuk dilakukannya suatu kegiatan. Peluang adalah keuntungan dan kekuatan pendorong untuk suatu kegiatan berlangsung. Oleh karena itu, peluang memiliki karakteristik positif dan menguntungkan. Untuk manajemen perusahaan, peluang adalah waktu atau situasi yang diberikan lingkungan kepada perusahaan untuk mencapai tujuannya. Peluang adalah peluang yang akan menghasilkan hasil positif bagi perusahaan yang ditentukan sebagai hasil analisis lingkungannya.

Ancaman (Threats) adalah situasi atau kondisi yang membahayakan aktifitas perusahaan. Hal ini merujuk pada situasi yang tidak menguntungkan. Pleh karena itu ancaman memiliki karakteristik negatif yang harus dihindari. Untuk manajemen, ancaman 
adalah elemen yang membuat sulit atau tidak mungkin untuk mencapai tujuan perusahaan. Ancaman adalah situasi yang muncul sebagai akibat dari perubahan lingkungan langsung yang akan mencegah perusahaan mempertahankan eksistensinya atau kehilangan keunggulannya dalam persaingan, dan yang tidak menguntungkan bagi perusahaan. Hal ini dapat menjadi penghalang bagi keberhasilan perusahaan, dan menyebabkan kerusakan yang tidak dapat dipulihkan.

Analisis SWOT adalah teknik analisis yang memiliki perspektif umum dan menyajikan solusi umum. Detail dan masalah spesifik bukan fokus Analisis SWOT, tetapi analisis lain yang akan mengikuti. Sebagai alat analisis, SWOT memberikan kesempatan untuk fokus pada aspek-aspek positif dan negatif dari lingkungan internal dan eksternal organisasi, dengan kata lain elemen-elemen dalam lingkungan ini yang menambah nilai plus dan minus, semuanya bersama-sama dalam perspektif terkait. Dalam hal ini, juga dimungkinkan untuk menggambarkan Analisis SWOT sebagai 'Matriks Dua-Dua'.

Tabel 3. Matriks Analisis SWOT

\begin{tabular}{|c|c|c|}
\hline & Kekuatan (Strenghts) & Kelemahan (Weaknesses) \\
\hline \multirow{2}{*}{$\begin{array}{l}\text { Peluang } \\
\text { (Opportunities) }\end{array}$} & Strategi S-O & Strategi W-O \\
\hline & $\begin{array}{l}\text { Mendapatkan peluang yang sangat } \\
\text { sesuai dengan kekuatan organisasi }\end{array}$ & $\begin{array}{l}\text { Mengatasi kelemahan } \\
\text { mendapatkan peluang }\end{array}$ \\
\hline \multirow[b]{2}{*}{ Ancaman (Threats) } & Strategi S-T & Strategi W-T \\
\hline & $\begin{array}{l}\text { Gunakan kekuatan untuk mengurangi } \\
\text { kerentanan organisasi } \\
\text { ancaman }\end{array}$ & $\begin{array}{l}\text { Mencegah kelemahan agar tidak } \\
\text { membuat organisasi lebih rentan } \\
\text { terhadap ancaman }\end{array}$ \\
\hline
\end{tabular}

Ege dan Yasar, (2017)

\section{METODE PENELITIAN}

Metode penelitian yang digunakan dalam penelitian ini adalah metode deskriptif. Penelitian deskriptif merupakan prosedur penelitian yang menghasilkan data deskriptif berupa kata-kata tertulis atau lisan dari orang-orang dan perilaku yang diamati. Penelitian deskriptif sering dikatakan sebgai sebuah penelitian tanpa eksperimen karena peneliti tidak dapat memanipulasi variabel penelitian (Parrangan dkk, 2015). Jenis penelitian deskriptif yang digunakan dalam penelitian adalah penelitian studi kasus yang diambil dari industri manufaktur kimia pada PT. ABC. Studi ini biasa digunakan untuk menganalisis kejadian, fenomena, atau keadaan secara sosial. Penelitian studi kasus memusatkan diri secara intensif terhadap satu objek tertentu, dengan cara mempelajari sebagai suatu kasus.

Teknik pengumpulan data merupakan metode yang digunakan oleh peneliti dalam mengumpulkan data-data yang diperlukan. Pengumpulan data ini bukan hanya mengamati obyek melainkan semua bentuk pengumpulan data yang diperlukan. Teknik pengumpulan data yang digunakan dalam penelitian:

a. Penelitian Lapangan (Field Work Research), dilakukan untuk mendapatkan data dengan cara melakukan observasi langsung terhadap aktivitas dan kegiatan perusahaan dari dekat, dengan menggunakan metode : pengamatan (observasi) dan wawancara (interview) kepada pihak-pihak terkait.

b. Penelitian Kepustakaan (Library Research), dilakukan untuk mengumpulkan data 
sekunder atau data yang diperoleh dari data yang telah dibukukan, baik berupa tulisan para ahli di bidangnya, laporan hasil penelitian dan jurnal penelitian yang telah lebih dulu ada.

Analisis data dalam penelitian ini dilakukan untuk mengetahui strategi bersaing perusahaan dalam industri manufaktur kimia. Dari analisis tersebut peneliti menganalisis rekomendasi strategi yang paling tepat yang diterapkan di PT. ABC dan dapat menjadi alternatif bagi perusahaan di masa depan. Metode analisis data pada penelitian yang digunakan yaitu dengan menggunakan analisis SWOT dengan menggunakan matriks IFAS dan EFAS yang kemudian disusun ke dalam Matriks SWOT untuk mengertahui strategi yang dapat direkomendasikan kepada perusahaan.

\section{HASIL DAN PEMBAHASAN}

Analisis SWOT (strengths, weaknesses, opportunities, dan threats) merupakan salah satu metode analisis yang dilakukan dalam melakukan penyusunan strategi perusahaan dengan melihat kondisi lingkungan perusahaan baik dari lingkungan internal maupun eksternal. Analisis SWOT digunakan untuk melihat kekuatan, kelemahan, peluang dan ancaman yang akan dihadapi oleh perusahaan (Shobirin dan Ali, 2019). Berdasarkan hasil wawancara dan observasi maka diketahui tentang analisis internal dan analisis eksternal dari PT. ABC yang akan digunakan sebagai perumusan strategi bersaing perusahaan.

\section{Kekuatan (Strengths)}

1. Sumber daya manusia yang berkompeten dan berpengalaman.

2. Kapasitas produksi salah satu produk turunan terbesar.

3. Memiliki pasar ekspor yang besar.

4. Kualitas produk yang baik di pasar.

5. Menggunakan bahan baku yang berkualitas.

\section{Kelemahan (Weaknesses)}

1. Teknologi produksi yang digunakan belum teknologi yang baru.

2. Lemah dari segi keuangan.

3. Kurangnya armada logistik untuk pengiriman barang.

4. Kolaborasi antar bagian yang masih kurang.

5. R\&D produk yang tidak berkembang.

\section{Peluang (Opportunities)}

1. Permintaan pasar yang terus meningkat dan beragam.

2. Lokasi yang strategis, berada dekat dengan kawasan industri pengguna.

3. Terbukanya penggunaan teknologi yang baru.

4. Hubungan baik dengan pelanggan sudah terjalin sejak lama.

5. Luasnya jaringan pemasaran dengan mitra perusahaan.

\section{Ancaman (Threats)}

1. Rentan terhadap perubahan kenaikan kurs USD.

2. Perubahan strategi pesaing.

3. Munculnya kompetior baru.

4. Kenaikan UMR yang relatif tinggi tiap tahunnya.

5. Produk dari RRC yang lebih murah dengan volume banyak.

Dari hasil analisis terhadap faktor internal perusahaan, yaitu kekuatan (strength) dan kelemahan (weakness) dan faktor ekstenal meliputi peluang (opportunity) dan ancaman 
(threat), kemudian hasil analisis disajikan dengan menggunakan Matriks IFAS dan EFAS pada Tabel 4 dan Tabel 5. Penentuan bobot dalam analisis Internal Factor Analysis Strategy (IFAS) dan External Factor Analysis Strategy (EFAS) ditentukan oleh penulis yang berperan sebagai instrumen penelitian. Landasan dari pemberian nilai bobot dalam analisis IFAS dan EFAS berpedoman kepada jawaban yang dipaparkan oleh responden.

Tabel 4. Matriks Internal Factor Analysis Strategy (IFAS)

\begin{tabular}{|c|c|c|c|c|}
\hline No. & $\begin{array}{l}\text { Internal Factor Analysis Strategy } \\
\text { Kekuatan/Strenghts }\end{array}$ & Bobot & Rating & Nilai \\
\hline 1 & Sumber daya manusia yang berkompeten dan berpengalaman & 0.09 & 3 & 0.27 \\
\hline 2 & Kapasitas produksi salah satu produk turunan terbesar & 0.20 & 4 & 0.80 \\
\hline 3 & Memiliki pasar ekspor yang besar & 0.10 & 4 & 0.40 \\
\hline 4 & Kualitas produk yang baik di pasar & 0.15 & 4 & 0.60 \\
\hline \multirow[t]{3}{*}{5} & Menggunakan bahan baku yang berkualitas & 0.10 & 3 & 0.30 \\
\hline & Sub Total & 0.64 & & 2.37 \\
\hline & Kelemahan/Weaknesses & & & \\
\hline 1 & Teknologi produksi yang digunakan belum teknologi yang baru & 0.10 & 3 & 0.30 \\
\hline 2 & Lemah dari segi keuangan & 0.06 & 4 & 0.24 \\
\hline 3 & Kurangnya armada logistik untuk pengiriman barang & 0.06 & 2 & 0.12 \\
\hline 4 & Kolaborasi antar bagian yang masih kurang & 0.05 & 2 & 0.10 \\
\hline \multirow[t]{3}{*}{5} & R\&D produk yang tidak berkembang & 0.09 & 3 & 0.27 \\
\hline & Sub Total & 0.36 & & 1.03 \\
\hline & Jumlah & 1.00 & & 3.40 \\
\hline
\end{tabular}

Tabel 5. Matriks External Factor Analysis Strategy (EFAS)

\begin{tabular}{|c|c|c|c|c|}
\hline No. & $\begin{array}{l}\text { External Factor Analysis Strategy } \\
\text { Peluang/Opportunities }\end{array}$ & Bobot & Rating & Nilai \\
\hline 1 & Permintaan pasar yang terus meningkat dan beragam & 0.20 & 4 & 0.80 \\
\hline 2 & $\begin{array}{l}\text { Lokasi yang strategis, berada dekat dengan kawasan industri } \\
\text { pengguna }\end{array}$ & 0.15 & 3 & 0.45 \\
\hline 3 & Terbukanya penggunaan teknologi yang baru & 0.10 & 3 & 0.30 \\
\hline 4 & Hubungan baik dengan pelanggan sudah terjalin sejak lama & 0.08 & 4 & 0.32 \\
\hline \multirow[t]{3}{*}{5} & Luasnya jaringan pemasaran dengan mitra perusahaan & 0.07 & 2 & 0.14 \\
\hline & Sub Total & 0.60 & & 2.01 \\
\hline & Ancaman/Threats & & & \\
\hline 1 & Rentan terhadap perubahan kenaikan kurs USD & 0.12 & 3 & 0.36 \\
\hline 2 & Perubahan strategi pesaing & 0.07 & 2 & 0.14 \\
\hline 3 & Munculnya kompetior baru & 0.05 & 2 & 0.10 \\
\hline
\end{tabular}


$4 \quad$ Kenaikan UMR yang relatif tinggi tiap tahunnya

$0.08 \quad 3$

$5 \quad$ Produk dari RRC yang lebih murah dengan volume banyak

$0.08 \quad 2 \quad 0.16$

\begin{tabular}{cccc}
\hline Sub Total & & 0.40 & 1.00 \\
\hline & Jumlah & 1.00 & 3.01 \\
\hline
\end{tabular}

Hasil dari matriks IFAS dan EFAS dibandingkan untuk mengetahui strategi alternatif (SO, ST, WO, dan WT). Kemudian menentukan strategi yang dapat digunakan oleh PT. $\mathrm{ABC}$ dalam menghadapi persaingan bisnis.

Tabel 6. Matriks SWOT

\begin{tabular}{|c|c|c|}
\hline \multirow{6}{*}{ EFAS } & Kekuatan (Strengths) & Kelemahan (Weaknesses) \\
\hline & $\begin{array}{l}\text { 1. Sumber daya manusia yang } \\
\text { berkompeten dan berpengalaman }\end{array}$ & $\begin{array}{l}\text { 1. Teknologi produksi yang digunakan } \\
\text { belum teknologi yang baru }\end{array}$ \\
\hline & $\begin{array}{l}\text { 2. Kapasitas produksi salah satu produk } \\
\text { turunan terbesar }\end{array}$ & 2. Lemah dari segi keuangan \\
\hline & 3. Memiliki pasar ekspor yang besar & $\begin{array}{l}\text { 3. Kurangnya armada logistik untuk } \\
\text { pengiriman barang }\end{array}$ \\
\hline & 4. Kualitas produk yang baik di pasar & $\begin{array}{l}\text { 4. Kolaborasi antar bagian yang masih } \\
\text { kurang }\end{array}$ \\
\hline & $\begin{array}{l}\text { 5. Menggunakan bahan baku yang } \\
\text { berkualitas }\end{array}$ & 5. R\&D produk yang tidak berkembang \\
\hline Peluang (Opportunities) & Strategi S - O & Strategi W - O \\
\hline $\begin{array}{l}\text { 1. Permintaan pasar yang terus } \\
\text { meningkat dan beragam }\end{array}$ & $\begin{array}{l}\text { 1. Meningkatkan kapasitas produksi } \\
\text { dengan ekspansi pabrik }\end{array}$ & $\begin{array}{l}\text { 1. Memperbarui teknologi produksi yang } \\
\text { lebih efisien }\end{array}$ \\
\hline $\begin{array}{l}\text { 2. Lokasi yang strategis, berada dekat } \\
\text { dengan kawasan industri pengguna }\end{array}$ & $\begin{array}{l}\text { 2. Memperluas target pemasaran dengan } \\
\text { memanfaatkan jaringan yang sudah ada }\end{array}$ & $\begin{array}{l}\text { 2. Menambah armada untuk pengiriman } \\
\text { barang yang lebih cepat ke pelanggan }\end{array}$ \\
\hline $\begin{array}{l}\text { 3. Terbukanya penggunaan teknologi } \\
\text { yang baru }\end{array}$ & $\begin{array}{l}\text { 3. Konsisten menjaga kualitas produk } \\
\text { tetap baik }\end{array}$ & $\begin{array}{l}\text { 3. Memperkuat bagian } \mathrm{R} \& \mathrm{D} \text { untuk } \\
\text { mengembangkan produk turunan yang } \\
\text { lebih bernilai }\end{array}$ \\
\hline $\begin{array}{l}\text { 4. Hubungan baik dengan pelanggan } \\
\text { sudah terjalin sejak lama }\end{array}$ & $\begin{array}{l}\text { 4. Menambah gudang di Surabaya untuk } \\
\text { merambah pasar Indonesia timur }\end{array}$ & \\
\hline $\begin{array}{l}\text { 5. Luasnya jaringan pemasaran } \\
\text { dengan mitra perusahaan }\end{array}$ & & \\
\hline Ancaman (Threats) & Strategi S - T & Strategi W - T \\
\hline $\begin{array}{l}\text { 1. Rentan terhadap perubahan } \\
\text { kenaikan kurs USD }\end{array}$ & $\begin{array}{l}\text { 1. Mencari sourching bahan baku lokal } \\
\text { yang sesuai dengan kualitas diinginkan }\end{array}$ & $\begin{array}{l}\text { 1. Melakukan strategi cost leadership dan } \\
\text { differentiation untuk memperluas target } \\
\text { pemasaran dan segmen industri }\end{array}$ \\
\hline 2. Perubahan strategi pesaing & $\begin{array}{l}\text { 2. Meningkatkan soft skill karyawan } \\
\text { dengan program pendidikan dan } \\
\text { pelatihan yang berkelanjutan }\end{array}$ & $\begin{array}{l}\text { 2. Negosiasi dengan supplier bahan baku } \\
\text { import supaya memperoleh harga bahan } \\
\text { baku yang lebih murah }\end{array}$ \\
\hline 3. Munculnya kompetior baru & $\begin{array}{l}\text { 3. Menjaga hubungan dengan pelanggan } \\
\text { yang sudah ada dengan program } \\
\text { kemitraan }\end{array}$ & $\begin{array}{l}\text { 3. Memaksimalkan potensi keuangan yang } \\
\text { ada }\end{array}$ \\
\hline $\begin{array}{l}\text { 4. Kenaikan UMR yang relatif tinggi } \\
\text { tiap tahunnya }\end{array}$ & $\begin{array}{l}\text { 4. Mulai melakukan otomatisasi unit } \\
\text { mesin produksi }\end{array}$ & \\
\hline $\begin{array}{l}\text { 5. Produk dari RRC yang lebih murah } \\
\text { dengan volume banyak }\end{array}$ & & \\
\hline
\end{tabular}

Berdasarkan matriks SWOT yang disajikan pada Tabel 6, maka dapat diketahui 
strategi dari empat kudran yang tersedia dengan memanfaatkan kekuatan, kelemahan, peluang, serta ancaman yang telah dianalisis sebelumnya, berikut adalah penjelasan dari strategi yang diperoleh dari matriks SWOT.

\section{Strategi S-O (Strengths - Opportunities)}

Strategi ini menciptakan strategi dengan menggunakan kekuatan dari perusahaan untuk memanfaatkan peluang yang ada. Berikut adalah strategi yang dihasilkan :

1) Meningkatkan kapasitas produksi dengan ekspansi pabrik.

2) Memperluas target pemasaran dengan memanfaatkan jaringan yang sudah ada.

3) Konsisten menjaga kualitas produk tetap baik.

4) Menambah gudang di Surabaya untuk merambah pasar Indonesia timur.

\section{Strategi S - T (Srengths - Threats)}

Strategi ini digunakan untuk menciptakan strategi dengan menggunakan kekuatan yang dimiliki oleh perusahaan untuk mengatasi ancaman. Berikut adalah strategi yang dihasilkan :

1) Mencari sourching bahan baku lokal yang sesuai dengan kualitas diinginkan.

2) Meningkatkan soft skill karyawan dengan program pendidikan dan pelatihan yang berkelanjutan.

3) Menjaga hubungan dengan pelanggan yang sudah ada dengan program kemitraan.

4) Mulai melakukan otomatisasi unit mesin produksi.

\section{Strategi W - O (Weaknesses - Opportunities)}

Strategi ini diterapkan dengan cara memanfaatkan peluang yang dimiliki perusahaan untuk meminimalkan kelemahan yang dimiliki perusahaan. Berikut adalah beberpa startegi yang dihasilkan:

1) Memperbarui teknologi produksi yang lebih efisien.

2) Menambah armada untuk pengiriman barang yang lebih cepat ke pelanggan.

3) Memperkuat bagian R\&D untuk mengembangkan produk turunan yang lebih bernilai.

\section{Strategi W - T (Weaknesses - Threats)}

Strategi ini digunakan pada strategi defensif, dimana strategi ini diciptakan untuk meminimalkan kelemahan yang dimiliki perusahaan serta menghindari ancaman. Berikut adalah strategi yang dihasilkan:

1) Melakukan strategi cost leadership dan differentiation untuk memperluas target pemasaran dan segmen industri.

2) Negosiasi dengan supplier bahan baku import supaya memperoleh harga bahan baku yang lebih murah.

3) Memaksimalkan potensi keuangan yang ada.

Strategi yang dihasilkan dari mariks SWOT dapat memberikan beberapa alternatif strategi yang dapat dipertimbangkan dan digunakan oleh perusahaan untuk dapat bersaing dengan kompetitornya dan bahkan dapat mengembangkan bisnisnya lebih lanjut. 


\section{KESIMPULAN DAN SARAN}

Berdasarkan hasil analisis internal dan eksternal perusahaan yang telah dilakukan dan kemudian dilanjutkan dengan melakukan analisis SWOT untuk perancanaan strategi bersaing PT. ABC dalam industri manufaktur kimia, maka dapat ditarik kesimpulan sebagai berikut :

1. Dari hasil analisis SWOT yang telah dilakukan menunjukan bahwa PT. ABC berada pada kuadran I dimana perusahaan memiliki kekuatan pada pemasaran dan produk. Hal ini menunjukkan bahwa PT. ABC banyak memiliki peluang di pasar jika dapat menggunakan strategi yang tepat.

2. PT. ABC memiliki peluang besar untuk tumbuh dan menambah pasar pemasaran serta melakukan ekspansi pabrik karena sudah memiliki jaringan pemasaran yang baik dan sudah lama.

3. PT. ABC memiliki pasar ekspor yang sudah besar dan masih dapat terus dikembangkan dengan strategi cost leadership dan differentiation.

4. Penggunaan analisis SWOT mampu menggambarkan situasi dan kondisi perusahaan saat ini baik di lingkungan internal dan juga lingkungan eksternal perusahaan, sehingga perusahaan dapat merancang strategi yang dapat digunakan untuk menghindari ancaman di masa yang akan datang dan bahkan dapat unggul dalam persaingan bisnis.

Adapun saran yang dapat disampaikan dari hasil penelitian ini adalah sebagai berikut :

1. Dalam menghadapi ancaman yang akan datang dari kompetitor baik dari lokal maupun luar negeri, PT. ABC sebaiknya dapat mencari dan memanfaatkan bahan baku dari lokal dengan kualitas yang baik untuk mengurangi ancaman eksternal.

2. Sebaiknya PT. ABC memperbaiki komunikasi antar bagian dan memperkuat bagian logistik pengiriman untuk pengiriman yang lebih cepat dan baik untuk mencapai kepuasan pelanggan.

3. Sebaiknya bagian R\&D produk dari PT. ABC dikembangkan lagi untuk dapat menciptakan produk yang lebih bervariasi dan lebih bernilai sehingga PT. ABC dapat menjadi market leader untuk produk yang dikembangkan sendiri.

4. Sebaiknya modernisasi peralatan produksi untuk efisiensi proses yang lebih baik dan pengembangan soft skill karyawan perlu dilakukan, karena tuntutan pasar saat ini semakin ketat mengenai harga dan kualitas, sedangkan biaya tenaga kerja tiap tahun meningkat sehingga tidak membebani keuangan perusahaan di kemudian hari.

\section{DAFTAR RUJUKAN}

Badan Pusat Statistik. 2020. Pertumbuhan Produksi IBS Tahun 2019 Naik 4,01 Persen dibandingkan Tahun 2018. [Online] Tersedia : https://www.bps.go.id/pressrelease/2020/02/03/1739/pertumbuhan-produksi-ibstahun-2019-naik-4-01-persen-dibandingkan-tahun-2018.html. [2 April 2020].

Brata, B.H., Husani, S., dan Ali, H. 2017. "The Influence of Quality Products, Price, Promotion, and Location to Product Purchase Decision on Nitchi at PT. Jaya Swarasa Agung in Central Jakarta". Saudi Journal of Business and Management Studies. Vol. 2, pp: 433-445.

David, F.R. 2009. Strategic Management. Edisi Kedua belas. New Jersey: Pearson Prentice Hall.

Ege dan Yasar. 2017. "Swot Analysis: A Theoretical Review". The Journal of International 
Social Research. Vol. 10 (51), pp: 994-1006.

Hakim, M.L., Aini, F.I.N., Hendrianie, N. dan Juliastuti, S.R. 2018. "Pra Desain Pabrik Asam Sulfat dari Belerang dengan Proses Doubel Kontak Doubel Absorber", Jurnal Teknik ITS, Vol. 7 (1), pp: 2337-3520.

Parrangan, E.R., Kumadji, S. dan Yulianto, E. 2015. “Analisis Strategi Perusahaan dalam Ekspansi Pasar Luar Negeri (Studi Kasus Pada PT. Semen Indonesia (Persero) Tbk dalam Akuisisi Thang Long Cement Company di Vietnam)", Jurnal Administrasi Bisnis, Vol. 26 (2), pp: 1-10.

Rangkuti, F. 2014. Analisis SWOT : Cara Perhitungan Bobot, Rating dan OCAI. Jakarta: PT. Gramedia Pustaka Utama.

Shobirin, M. dan Ali, H. 2019. "Strategi Pengembangan Infrastruktur dalam Meningkatkan Pelayanan Penumpang di Bandar Udara Internasional Soekarno Hatta Cengkareng”. Jurnal Ekonomi dan Manajemen Sistem Informasi, Vol. 3 (2), pp: 155-168. 